\title{
Article \\ Estimation of Nitrogen Use Efficiency for Ryegrass-Fed Dairy Cows: Model Development Using Diet- and Animal-Based Proxy Measures
}

\author{
Wumaierjiang Aizimu ${ }^{1}$, Omar Al-Marashdeh ${ }^{2, *} \mathbb{C}$, Simon Hodge ${ }^{3}{ }^{(}$, Richard J. Dewhurst $^{4}$, Ao Chen ${ }^{2}$, \\ Guangyong Zhao ${ }^{5}$, Saranika Talukder ${ }^{6, *}$, Grant R. Edwards ${ }^{2}$ and Long Cheng ${ }^{7, *}$ (D) \\ 1 College of Animal Science, Tarim University, Alar 843300, Xinjiang, China; wumaier@tom.com \\ 2 Faculty of Agriculture and Life Sciences, Lincoln University, P.O. Box 85084, \\ Lincoln 7674, Canterbury, New Zealand; coldchenao@gmail.com (A.C.); \\ Grant.Edwards@lincoln.ac.nz (G.R.E.) \\ 3 School of Agriculture and Food Science, University College Dublin, Belfield, Dublin 4, Ireland; \\ simon.hodge@ucd.ie \\ 4 Scotland's Rural College, King's Buildings, West Mains Road, Edinburgh EH9 3JG, UK; \\ richard.dewhurst@sruc.ac.uk \\ 5 State Key Laboratory of Animal Nutrition, College of Animal Science and Technology, China Agricultural \\ University, Beijing 100193, China; zhaogy@cau.edu.cn \\ 6 Faculty of Veterinary and Agricultural Science, University of Melbourne, Parkville, VIC 3010, Australia \\ 7 Faculty of Veterinary and Agricultural Science, University of Melbourne, Dookie, VIC 3647, Australia \\ Citation: Aizimu, W.; Al-Marashdeh, \\ * Correspondence: omar.al-marashdeh@lincoln.ac.nz (O.A.-M.); saranika.talukder@unimelb.edu.au (S.T.); \\ long.cheng@unimelb.edu.au (L.C.)
} O.; Hodge, S.; Dewhurst, R.J.; Chen, A.; Zhao, G.; Talukder, S.; Edwards,

G.R.; Cheng, L. Estimation of

Nitrogen Use Efficiency for

Ryegrass-Fed Dairy Cows: Model

Development Using Diet- and Animal-Based Proxy Measures. Dairy 2021, 2, 435-451. https://doi.org/ 10.3390/dairy2030035

Academic Editor: Monica

Isabella Cutrignelli

Received: 9 June 2021

Accepted: 21 July 2021

Published: 16 August 2021

Publisher's Note: MDPI stays neutral with regard to jurisdictional claims in published maps and institutional affiliations.

Abstract: This study aimed to identify suitable predictors of nitrogen (N) use efficiency (NUE; milk $\mathrm{N} / \mathrm{N}$ intake) for cows that differed in breeds and were fed with ryegrass pasture, using existing data from the scientific literature. Data from 16 studies were used to develop models based on the relationships between NUE and dietary and animal-based factors. Data from a further 10 studies were used for model validation. Milk urea N (MUN) and dietary water-soluble carbohydrate-tocrudeprotein ratio (WSC/CP) were the best and most practical animal- and diet-based proxies to predict NUE. The results indicate that it might be necessary to adopt separate models for different breeds when using WSC/CP to predict NUE but not when using MUN.

Keywords: crude protein; Friesian; Jersey; milk urea nitrogen; soluble carbohydrates

\section{Introduction}

Prediction of nitrogen (N) use efficiency (NUE; milk N/N intake) of dairy cows at a herd or farm level is essential to support the development of sustainable dairy production, as it relates to the farm productivity, profitability, and environmental footprint [1-4]. In temperate grassland regions (e.g., Ireland), dairy cows are commonly grazed on pastures containing blends of perennial ryegrass (Lolium perenne) and white clover (Trifolium repens), which typically have high levels of $\mathrm{N}$ (ranges between 3.0 and $4.8 \%$ of DM) relative to dairy cow requirements for milk production [5]. This oversupply of dietary $\mathrm{N}$ results in low NUE and high (more than $50 \%$ of $\mathrm{N}$ intake) urinary $\mathrm{N}$ excretion, leading to increased $\mathrm{N}$ loss to the environment via nitrate leaching and nitrous oxide emission [5]. To estimate NUE of dairy cows, it is necessary to measure feed intake, which can be costly and difficult to accomplish with large numbers of grazing dairy cows. Therefore, there is an increased interest in estimating dairy cow NUE from easily obtained diet- and animal-based proxies [6,7].

Milk urea N (MUN) has been developed as a proxy measure of NUE in studies using mixed rations $[8,9]$. However, limited studies have investigated the usefulness of MUN to predict dairy cow NUE in pasture-based systems [10-12]. Previous studies indicated that NUE might be estimated from feed composition, such as the content of crude protein $(\mathrm{CP})$ or 
water-soluble carbohydrates (WSC) [2,6]. However, these models were developed using a limited number of studies, and many earlier studies did not account for differences between breeds, despite that breed was shown to affect animal parameters such as MUN [13,14].

The study aimed to utilise data from the scientific literature and evaluate a range of diet- and animal-based measures since their value in predictive models for measuring NUE under pasture-based dairy cows. In addition, to examine the applicability of the resultant models to different cow breeds, we evaluated the models involving Friesian and Jersey $\times$ Friesian cows.

\section{Material and Methods}

\subsection{Data Collection and Parameter Estimation}

A literature search was conducted for the tenure (1996-2011) with the following keywords in Google Scholar: nitrogen use efficiency; ryegrass; cows; diet; milk urea; Friesian. Based on that search, studies between Friesian and Jersey $\times$ Friesian fed with a diet composed of more than $50 \%$ perennial ryegrass were selected in this study (Table 1 ). The studies were published between 1996 and 2011, and some unpublished data from 2013 were also made available by personal communication. Those studies were carried out at three locations of the South and North Island of New Zealand. The data obtained and used in this study were treatment means, with group sizes ranging between 3 and 30 cows (Table 1).

Table 1. Summary information about sources of data used in model development (Trial 1-16) and evaluation (Trial 17-26).

\begin{tabular}{|c|c|c|c|c|c|c|}
\hline Study & Year & $\begin{array}{c}\text { Groups of } \\
\text { Cows in Study }\end{array}$ & $\begin{array}{l}\text { Cows per } \\
\text { Group }\end{array}$ & Breed & Region & Reference \\
\hline 1 & 1997 & 4 & 8 & $F$ & NZ & [15] \\
\hline 2 & 1999 & 3 & 15 & $\mathrm{~F}$ & NZ & [16] \\
\hline 3 & 2003 & 4 & 4 & $\mathrm{~F}$ & NZ & [17] \\
\hline 4 & 2009 & 14 & $20-30$ & $\mathrm{~F}$ & NZ & [18] \\
\hline 5 & 2009 & 2 & 5 & $\mathrm{~F}$ & NZ & [19] \\
\hline 6 & 2010 & 8 & 15 & $\mathrm{~F}$ & NZ & [20] \\
\hline 7 & 1996 & 8 & 8 & JF & NZ & [21] \\
\hline 8 & 1997 & 6 & 3 & $\mathrm{JF}$ & NZ & [22] \\
\hline 9 & 1998 & 3 & 5 & $\mathrm{JF}$ & NZ & [23] \\
\hline 10 & 2006 & 2 & 8 & $\mathrm{JF}$ & NZ & [24] \\
\hline 11 & 2010 & 2 & 18 & $\mathrm{JF}$ & NZ & [3] \\
\hline 12 & 2010 & 3 & 5 & $\mathrm{JF}$ & NZ & Cheng unpublished 2010 \\
\hline 13 & 2010 & 4 & 10 & $\mathrm{JF}$ & NZ & [25] \\
\hline 14 & 2011 & 1 & 8 & JF & NZ & [26] \\
\hline 15 & 2012 & 4 & 12 & $\mathrm{JF}$ & NZ & [27] \\
\hline 16 & 2013 & 4 & 8 & JF & NZ & Cheng unpublished 2013 \\
\hline 17 & 2005 & 2 & $4-8$ & $\mathrm{~F}$ & Netherlands & [28] \\
\hline 18 & 2006 & 3 & 4 & $\mathrm{~F}$ & Netherlands & [29] \\
\hline 19 & 2009 & 2 & 10 & $\mathrm{~F}$ & Netherlands & [30] \\
\hline 20 & 2013 & 4 & 8 & $\mathrm{~F}$ & Ireland & [31] \\
\hline 21 & 2010 & 3 & 16 & $\mathrm{~F}$ & NZ & [32] \\
\hline 22 & 2013 & 3 & 12 & JF & NZ & [33] \\
\hline 23 & 2014 & 6 & 6 & $\mathrm{JF}$ & NZ & [34] \\
\hline 24 & 2015 & 2 & 5 & $\mathrm{JF}$ & NZ & [35] \\
\hline 25 & 2015 & 3 & 3 & JF & NZ & [36] \\
\hline 26 & 2016 & 9 & 4 & $\mathrm{JF}$ & NZ & [37] \\
\hline
\end{tabular}

(F-Friesian; JF-Jersey $\times$ Friesian).

The parameters extracted or calculated from the literature are summarised in Table 2, along with their units, abbreviations, and formulae used in calculations. Table 2 also shows the interrelationship of some of the variables and the derived measures often used to examine dairy system performance. Not all parameters listed in Table 2 were available or calculated across all studies since the required information was not provided. 
Table 2. Variables measured, units, abbreviations, and formulae for their calculation. If formulae have not been provided, variables were measured directly by chemical analysis.

\begin{tabular}{|c|c|c|c|c|}
\hline & Parameter & Abbreviation & Formula & Unit \\
\hline \multirow[t]{8}{*}{ Dietary factors } & Metabolisable energy & ME & & $(\mathrm{MJ} / \mathrm{kgDM})$ \\
\hline & Neutral detergent fibre & NDF & & $(\% \mathrm{DM})$ \\
\hline & Acid detergent fibre & $\mathrm{ADF}$ & & (\%DM) \\
\hline & Crude protein & $\mathrm{CP}$ & & (\%DM) \\
\hline & Water-soluble carbohydrate & WSC & & (\%DM) \\
\hline & Nitrogen & $\mathrm{N}$ & & $(\% \mathrm{DM})$ \\
\hline & $\begin{array}{l}\text { Water-soluble carbohydrate to } \\
\text { crude protein ratio }\end{array}$ & & WSC/CP & $(g / g)$ \\
\hline & $\begin{array}{l}\text { Metabolisable energy to crude } \\
\text { protein ratio }\end{array}$ & & $\mathrm{ME} / \mathrm{CP}$ & $(\mathrm{MJ} / \mathrm{g})$ \\
\hline \multirow[t]{14}{*}{ Animal factors } & Dry matter intake & DMI & & $(\mathrm{kg} / \mathrm{cow} / \mathrm{d})$ \\
\hline & ME intake & MEI & ME $\times$ DMI & $(\mathrm{MJ} / \operatorname{cow} / \mathrm{d})$ \\
\hline & Milk yield & MY & & $(\mathrm{kg} / \mathrm{cow} / \mathrm{d})$ \\
\hline & Milk nitrogen $\%$ & $\mathrm{MN} \%$ & & (\% volume) \\
\hline & Milk nitrogen & $\mathrm{MN}$ & $\mathrm{MN} \% \times \mathrm{MY} \times 10$ & $(\mathrm{~g} / \mathrm{cow} / \mathrm{d})$ \\
\hline & Milk protein $\%$ & $\mathrm{MP} \%$ & & (\% volume) \\
\hline & Milk protein & $\mathrm{MP}$ & $\mathrm{MN} \times 6.38 / 1000$ & $(\mathrm{~kg} / \mathrm{cow} / \mathrm{d})$ \\
\hline & Milk fat $\%$ & $\mathrm{MF} \%$ & & (\% volume) \\
\hline & Milk fat & MF & $\mathrm{MF} \% \times \mathrm{MY} / 100$ & $(\mathrm{~kg} / \mathrm{cow} / \mathrm{d})$ \\
\hline & Milk solids & MS & $\mathrm{MP}+\mathrm{MF}$ & $(\mathrm{kg} / \mathrm{cow} / \mathrm{d})$ \\
\hline & Nitrogen intake & NI & $\mathrm{DMI} \times \mathrm{N}$ & $(\mathrm{g} / \mathrm{cow} / \mathrm{d})$ \\
\hline & Urinary nitrogen & $\mathrm{UN}$ & & $(\mathrm{g} / \mathrm{cow} / \mathrm{d})$ \\
\hline & Faecal nitrogen & FN & & $(\mathrm{g} / \mathrm{cow} / \mathrm{d})$ \\
\hline & Milk urea nitrogen & MUN & & $(\mathrm{mmol} / \mathrm{L})$ \\
\hline \multirow[t]{8}{*}{ Derived measures } & Nitrogen use efficiency & NUE & $\mathrm{MN} / \mathrm{NI}$ & $(\mathrm{g} / \mathrm{g})$ \\
\hline & $\begin{array}{l}\text { Milk nitrogen to urinary } \\
\text { Nitrogen ratio }\end{array}$ & & $\mathrm{MN} / \mathrm{UN}$ & $(\mathrm{g} / \mathrm{g})$ \\
\hline & $\begin{array}{l}\text { Urinary nitrogen to Nitrogen } \\
\text { intake ratio }\end{array}$ & & $\mathrm{UN} / \mathrm{NI}$ & $(\mathrm{g} / \mathrm{g})$ \\
\hline & $\begin{array}{l}\text { Faecal nitrogen to urinary } \\
\text { Nitrogen ratio }\end{array}$ & & $\mathrm{FN} / \mathrm{UN}$ & $(g / g)$ \\
\hline & $\begin{array}{l}\text { Milk solids to dry matter } \\
\text { Intake ratio }\end{array}$ & & MS/DMI & $(\mathrm{kg} / \mathrm{kg})$ \\
\hline & $\begin{array}{l}\text { Milk yield to dry matter } \\
\text { Intake ratio }\end{array}$ & & MY/DMI & $(\mathrm{kg} / \mathrm{kg})$ \\
\hline & ME intake to milk yield ratio & & $\mathrm{MEI} / \mathrm{MY}$ & $(\mathrm{MJ} / \mathrm{kg})$ \\
\hline & ME intake to milk solid ratio & & $\mathrm{MEI} / \mathrm{MS}$ & $(\mathrm{MJ} / \mathrm{kg})$ \\
\hline
\end{tabular}

\subsection{Statistical Analysis and Model Development}

Statistical analyses were carried out using Genstat Version 15 (VSN International Ltd., Hemel Hempstead, UK). Summary statistics (means, standard error, minimum value, and maximum value) were calculated for each parameter using available group means. A stepwise process of model development was conducted, initially examining the basic correlations and later developing multiple regression and nonlinear mathematical functions. The sequence of model development is summarised as follows:

i. Rank correlations to examine the strength of monotonic relationships of each parameter with NUE, without making assumptions of the linearity of any relationships;

ii. Simple linear regression to identify linear relationships of the predictor parameters with NUE;

iii. For those parameters identified as having strong relationships with NUE from (i) and (ii), all subset regression procedures were performed to produce multiple regression models for NUE. These models were evaluated using Akaike information criterion (AIC) values and adjusted $R^{2}$ values, with high $R^{2}$ values and low AIC values indicat- 
ing a high predictive ability [38]. The goodness of fit was also examined visually by plotting predicted values to the observed NUE obtained from each study;

iv. Parameters identified as being included in the best multiple regression models in (iii) were then screened for their convenience in terms of ease of measurement and practical use as proxy measures;

v. For the parameters identified from (iv), linear and nonlinear (asymptotic curves) models were fitted for both breeds combined and separately for each breed to assess whether models were breed specific or applicable across Friesians and Jersey $x$ Friesian cows.

\subsection{Rank Correlations and Simple Linear Regression Models}

Since the initial screening process was conducted to examine the closeness of monotonic relationships between NUE and all the other parameters, rank correlation coefficients were calculated separately for Friesians and Jersey $\times$ Friesians. For any parameters showing significant rank correlations with NUE for both breeds and consistent relationships, simple linear regressions were performed. Both unweighted and weighted data were used to minimise the differences in the number of cows per group across studies (Table 1). There was no inclusion of 'study' as a random factor in these models since many of the covariates differed significantly between studies $[39,40]$.

\subsection{All Subset Regression Procedures and Multiple Regression Models}

From the simple linear regression models, a further selection of parameters was performed based on statistical significance $(p<0.01)$ for both breeds in weighted and unweighted models and the number of cases available for both breeds greater than 10 . From this process, six parameters were selected for further consideration, namely, $\mathrm{CP}, \mathrm{N}$, WSC/CP, N intake (NI), MUN, and MN/UN ratio. However, NI and MN are used in the calculation of NUE; thus, NI and MN/UN were judged as invalid predictors of NUE and not considered further.

Models were further evaluated for ease of measurement and practicality of application on the farm. From the all subset regression analysis, it was found that the animal-based parameter MUN and the dietary parameter WSC /CP produced the best estimates of NUE, which are independent variables and relatively easy for farmers to obtain.

\subsection{Evaluation of WSC/CP and MUN as Predictors of NUE}

A more detailed analysis of the relationship between NUE and WSC/CP and between NUE and MUN was performed. The relationships between NUE and WSC/CP were positive and linear, and therefore, simple linear regression models were fitted, comparing overall trends and the trends within each breed.

For MUN, the relationships with NUE were negative and asymptotic, and therefore, curves of the form NUE $=a+b c^{\mathrm{MUN}}$, where $a, b$ and $c$ are constants, $c<1$ and $(a+b)$ represents the maximum achievable NUE when $M U N=0$. As these models included nonlinear functions, it was thought inappropriate to compare them using $R^{2}$ values [41]. Instead, the goodness of fit of the raw data to the models was assessed using $S$ (the standard error of the observations or standard error of the regression) calculated as the square root of the mean square error term from the regression model.

\subsection{Model Evaluation}

To evaluate the models predicting NUE from MUN and WSC/CP, data were obtained from a further ten studies, five involving pure Friesian cows and five involving Jersey $\times$ Friesian cows (Table 1). Data involving Jersey $\times$ Friesian cows were obtained from recent studies (2013-2016) conducted in New Zealand. These were the only available studies that we could find in New Zealand in which cows were fed a diet composed of more than $50 \%$ perennial ryegrass. However, it was not possible to find recent results involving pure Friesian cows in New Zealand, and therefore, data were obtained from Eu- 
ropean countries with similar ryegrass-based dairy systems (The Netherlands and Ireland) (Table 1).

The observed values of NUE were compared with those predicted using the breedspecific linear models relating NUE with WSC/CP and with the combined breed exponential model relating NUE with MUN (Models 7, 8, and 10). Lin's concordance was used as a measure of correspondence between observed and predicted NUE values [42], and deviation of the observed NUE values $\left(O_{i}\right)$ from those predicted $\left(P_{i}\right)$ by the models was quantified in the following four ways:

(i) Mean absolute error, $M A E=\left(\sum_{i=1}^{n}\left|O_{i}-P_{i}\right|\right) / n$;

(ii) Mean relative absolute error, $M R A E=\left[\sum_{i=1}^{n}\left(\frac{\left|O_{i}-P_{i}\right|}{O_{i}}\right) \times 100^{\%}\right] / n$;

(iii) Root mean square error, $R M S E=\sqrt{\sum_{i=1}^{n}\left(O_{i}-P_{i}\right)^{2} / n}$;

(iv) Normalised root mean square error, NRMSE $=($ RMSE $/$ mean $(\mathrm{Obs})) \times 100 \%$.

\section{Results}

\subsection{The Database, Rank Correlations, and Simple Linear Regression Models}

The data set covered a wide range of pasture quality (Table 3 ). For example, pasture CP content ranged from 11.6 to $28.0 \%$ of DM, metabolisable energy (ME) from 9.2 to $12.6 \mathrm{MJ} / \mathrm{kg}$ DM, neutral detergent fibre (NDF) from 34 to 59\% of DM, and WSC from 5 to 34\% of DM. The range of animal DMI was slightly larger for Jersey $\times$ Friesians $(10-19 \mathrm{~kg} / \mathrm{cow} / \mathrm{d})$ than for Friesians (12-17 kg DM/cow/d); however, the mean DMI was similar between the breeds (14.4 vs. $14.2 \mathrm{~kg}$ DM/cow/d for Friesians and Jersey $\times$ Friesians, respectively).

In the simple linear regressions, similar constants and slopes were obtained when using weighted or unweighted models (Table 4), and the directions of relationships with NUE were consistent between the two breeds. Of all single dietary factors, WSC/CP was the most accurate predictor of NUE, producing high adjusted $R^{2}$ values for both breeds (weighted models produced adjusted $R^{2}=77.0 \%$ and $72.4 \%$ for Friesians and Jersey $\times$ Friesians, respectively).

\subsection{All Subset Regression Analyses and Multiple Regression Models}

A subset regression procedure was performed with MUN, WSC/CP, N, and BREED as explanatory factors, with models being ranked in order of predictive ability using both adjusted $R^{2}$ and AIC values (Table 5). The model with the highest $R^{2}$ (and lowest AIC) included only MUN and WSC/CP (Models 1 and 2; Table 5). Forcing BREED into these models resulted in only a minor change in $R^{2}$ and AIC values (Models 3 and 4 ). The best model (based on AIC) when BREED was forced into the regression model omitted WSC /CP and contained only MUN and BREED (Model 5). However, when all available data for this model were used, the adjusted $R^{2}$ dropped to only 56.8\% (Model 6; Table 5).

\subsection{Practical Parameters: The Relationships of NUE with WSC/CP and MUN}

The relationship between NUE and WSC/CP was linear (Table 6; Figure 1). However, a model based on the data from both breeds of cows was not a good fit and produced a relatively high standard error of the observations (Table 6; Model 7). The interaction term between WSC/CP and BREED in a general linear model was highly significant $\left(\mathrm{F}_{1,41}=19.27 ; p<0.001\right)$, suggesting that separate models for NUE vs. WSC $/ \mathrm{CP}$ should be fitted to the different breeds (Figure 1). In support of this, the $95 \%$ CIs of the coefficients in the separate breed linear models relating NUE vs. WSC /CP showed no overlap (Models 8 and 9; Table 6). 


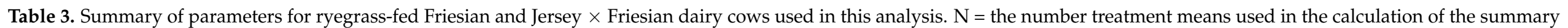
statistics for each parameter.

\begin{tabular}{|c|c|c|c|c|c|c|c|c|c|c|c|c|c|c|c|}
\hline & & \multicolumn{7}{|c|}{ Friesian } & \multicolumn{7}{|c|}{ Jersey $\times$ Friesian } \\
\hline & & $\mathbf{N}$ & Mean & SE & Min & $\operatorname{Max}$ & $r_{\mathrm{S}}$ & Sig. & $\mathbf{N}$ & Mean & SE & Min & Max & $r_{\mathrm{S}}$ & Sig. \\
\hline \multirow[t]{7}{*}{ Dietary factors } & $\mathrm{ME}(\mathrm{MJ} / \mathrm{kgDM})$ & 9 & 11.51 & 0.41 & 9.16 & 12.59 & 0.70 & $* * *$ & 37 & 11.80 & 0.09 & 9.87 & 12.70 & 0.45 & $* * *$ \\
\hline & NDF $(\%)$ & 28 & 45.67 & 1.47 & 33.80 & 59.00 & 0.04 & ns & 31 & 43.22 & 0.93 & 34.20 & 58.90 & -0.28 & * \\
\hline & $\operatorname{ADF}(\%)$ & 8 & 26.79 & 0.95 & 23.88 & 32.30 & 0.25 & ns & 18 & 24.12 & 1.02 & 18.70 & 32.20 & -0.02 & ns \\
\hline & $\mathrm{CP}(\%)$ & 29 & 20.00 & 0.89 & 11.88 & 28.00 & -0.52 & $* * *$ & 37 & 18.62 & 0.64 & 11.60 & 25.30 & -0.61 & $* * *$ \\
\hline & WSC $(\%)$ & 22 & 18.62 & 1.15 & 13.90 & 34.20 & 0.70 & $* * *$ & 24 & 19.23 & 0.99 & 5.00 & 28.70 & 0.13 & ns \\
\hline & WSC/CP $(\mathrm{g} / \mathrm{g})$ & 22 & 0.948 & 0.114 & 0.496 & 2.590 & 0.71 & $* * *$ & 23 & 1.092 & 0.068 & 0.674 & 1.780 & 0.57 & $* * *$ \\
\hline & $\mathrm{ME} / \mathrm{CP}(\mathrm{MJ} / \mathrm{g})$ & 9 & 0.731 & 0.051 & 0.537 & 0.928 & 0.90 & $* * *$ & 37 & 0.664 & 0.026 & 0.489 & 1.034 & 0.75 & $* * *$ \\
\hline \multirow[t]{11}{*}{ Animal factors } & MEI (MJ/cow/d) & 9 & 170.39 & 8.53 & 120.00 & 196.44 & 0.45 & ns & 37 & 167.81 & 5.95 & 116.20 & 229.20 & 0.03 & ns \\
\hline & $\mathrm{DMI}(\mathrm{kg} / \mathrm{cow} / \mathrm{d})$ & 29 & 14.40 & 0.27 & 12.28 & 16.60 & 0.43 & $* *$ & 37 & 14.20 & 0.47 & 10.20 & 19.10 & -0.07 & ns \\
\hline & $\mathrm{MY}(\mathrm{kg} / \mathrm{cow} / \mathrm{d})$ & 21 & 19.25 & 1.06 & 10.60 & 28.70 & 0.51 & $* *$ & 27 & 17.40 & 0.81 & 9.92 & 24.90 & -0.06 & ns \\
\hline & $\mathrm{MN}(\%)$ & 21 & 0.544 & 0.012 & 0.461 & 0.620 & -0.66 & $* * *$ & 27 & 0.600 & 0.012 & 0.511 & 0.706 & 0.70 & $* * *$ \\
\hline & $\mathrm{MN}(\mathrm{g} / \mathrm{cow} / \mathrm{d})$ & 35 & 105.42 & 3.52 & 58.32 & 160.00 & 0.24 & * & 37 & 99.14 & 3.91 & 55.82 & 150.00 & 0.38 & $* *$ \\
\hline & $\mathrm{MP}(\mathrm{kg} / \mathrm{cow} / \mathrm{d})$ & 35 & 0.677 & 0.022 & 0.372 & 1.021 & 0.24 & * & 31 & 0.644 & 0.025 & 0.356 & 0.957 & 0.31 & * \\
\hline & MF $(\%)$ & 13 & 4.141 & 0.343 & 1.530 & 5.490 & -0.28 & ns & 27 & 5.367 & 0.113 & 4.170 & 6.240 & 0.31 & * \\
\hline & $\mathrm{MF}(\mathrm{kg} / \mathrm{cow} / \mathrm{d})$ & 13 & 0.706 & 0.052 & 0.313 & 0.930 & 0.36 & ns & 27 & 0.889 & 0.028 & 0.545 & 1.210 & 0.05 & ns \\
\hline & $\mathrm{MS}(\mathrm{kg} / \mathrm{cow} / \mathrm{d})$ & 13 & 1.293 & 0.067 & 0.915 & 1.586 & 0.29 & ns & 27 & 1.542 & 0.053 & 0.901 & 1.944 & 0.22 & ns \\
\hline & $\mathrm{FN}(\mathrm{g} / \mathrm{cow} / \mathrm{d})$ & 4 & 121.75 & 4.19 & 114.00 & 129.00 & 0.65 & ns & 14 & 110.86 & 4.36 & 86.00 & 138.00 & 0.37 & $*$ \\
\hline & MUN (mmol/L) & 35 & 12.22 & 0.77 & 4.00 & 17.90 & -0.71 & $* * *$ & 33 & 10.10 & 0.78 & 3.17 & 17.60 & -0.81 & $* * *$ \\
\hline \multirow{7}{*}{$\begin{array}{l}\text { Derived } \\
\text { measures }\end{array}$} & MN/UN (g/g) & 18 & 0.515 & 0.058 & 0.279 & 1.210 & 0.93 & $* * *$ & 14 & 0.379 & 0.021 & 0.250 & 0.527 & 0.82 & $* * *$ \\
\hline & $\mathrm{UN} / \mathrm{NI}(\mathrm{g} / \mathrm{g})$ & 18 & 0.510 & 0.025 & 0.274 & 0.663 & -0.84 & $* * *$ & 14 & 0.538 & 0.021 & 0.458 & 0.722 & -0.42 & $*$ \\
\hline & MS/DMI (kg/kg) & 13 & 0.085 & 0.004 & 0.058 & 0.108 & 0.27 & ns & 27 & 0.108 & 0.003 & 0.069 & 0.138 & 0.52 & $* * *$ \\
\hline & $\mathrm{MY} / \mathrm{DMI}(\mathrm{kg} / \mathrm{kg})$ & 21 & 1.273 & 0.057 & 0.809 & 1.750 & 0.48 & $* *$ & 27 & 1.197 & 0.030 & 0.834 & 1.515 & 0.35 & $*$ \\
\hline & $\mathrm{MEI} / \mathrm{MY}(\mathrm{MJ} / \mathrm{kg})$ & 9 & 10.52 & 0.35 & 9.13 & 12.06 & -0.50 & $* *$ & 27 & 10.02 & 0.21 & 7.86 & 12.16 & -0.31 & $*$ \\
\hline & $\mathrm{MEI} / \mathrm{MS}(\mathrm{MJ} / \mathrm{kg})$ & 9 & 126.48 & 2.52 & 115.85 & 138.56 & -0.18 & ns & 27 & 112.23 & 2.98 & 89.41 & 143.09 & -0.53 & $* * *$ \\
\hline & NUE $(g / g)$ & 35 & 0.231 & 0.006 & 0.178 & 0.331 & & & 37 & 0.249 & 0.013 & 0.158 & 0.468 & & \\
\hline
\end{tabular}




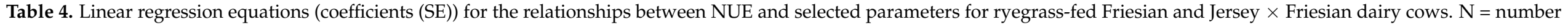
of group means used in each analysis. Models are given for both unweighted and weighted group means.

\begin{tabular}{|c|c|c|c|c|c|c|c|c|c|c|c|c|}
\hline & & \multirow[b]{2}{*}{ Weighted } & \multicolumn{5}{|c|}{ Friesian } & \multicolumn{5}{|c|}{ Jersey $\times$ Friesian } \\
\hline & & & $\mathbf{N}$ & Constant & Slope & Adj. $R^{2}(\%)$ & $p$ & $\mathbf{N}$ & Constant & Slope & Adj. $R^{2}(\%)$ & $p$ \\
\hline \multirow[t]{4}{*}{$\begin{array}{l}\text { Dietary } \\
\text { factors }\end{array}$} & $\mathrm{CP}(\%)$ & No & 29 & $0.326(0.025)$ & $-0.0047(0.0012)$ & 32.3 & $<0.001$ & 37 & $0.533(0.042)$ & $-0.0153(0.0022)$ & 55.9 & $<0.001$ \\
\hline & & Yes & 29 & $0.323(0.025)$ & $-0.0044(0.0012)$ & 33.0 & $<0.001$ & 37 & $0.597(0.041)$ & $-0.0186(0.0023)$ & 64.8 & $<0.001$ \\
\hline & WSC/CP (g/g) & No & 22 & $0.170(0.009)$ & $0.0665(0.0084)$ & 74.4 & $<0.001$ & 23 & $0.020(0.043)$ & $0.2144(0.0377)$ & 58.8 & $<0.001$ \\
\hline & & Yes & 22 & $0.166(0.009)$ & $0.0735(0.0087)$ & 77.0 & $<0.001$ & 23 & $0.020(0.036)$ & $0.2318(0.0303)$ & 72.4 & $<0.001$ \\
\hline \multirow{3}{*}{$\begin{array}{l}\text { Animal } \\
\text { factors }\end{array}$} & $\mathrm{NI}(\mathrm{g} /$ cow /d) & No & 35 & $0.317(0.027)$ & $-0.0002(0.0001)$ & 22.1 & 0.003 & 37 & $0.417(0.039)$ & $-0.0004(0.0001)$ & 34.3 & $<0.001$ \\
\hline & & Yes & 35 & $0.328(0.028)$ & $-0.0002(0.0001)$ & 27.1 & $<0.001$ & 37 & $0.480(0.036)$ & $-0.0005(0.0001)$ & 50.4 & $<0.001$ \\
\hline & & Yes & 35 & $0.324(0.009)$ & $-0.0075(0.0007)$ & 77.6 & $<0.001$ & 33 & $0.426(0.021)$ & $-0.0175(0.0022)$ & 66.1 & $<0.001$ \\
\hline \multirow{2}{*}{$\begin{array}{c}\text { Derived } \\
\text { measures }\end{array}$} & MN/UN (g/g) & No & 18 & $0.150(0.010)$ & $0.1725(0.0182)$ & 83.9 & $<0.001$ & 14 & $0.100(0.017)$ & $0.2593(0.0436)$ & 72.6 & $<0.001$ \\
\hline & & Yes & 18 & $0.138(0.012)$ & $0.2023(0.0234)$ & 81.3 & $<0.001$ & 14 & $0.096(0.019)$ & $0.2659(0.0480)$ & 69.5 & $<0.001$ \\
\hline
\end{tabular}


Table 5. Multiple regression models (coefficients (SE)) for NUE produced by all subset regression procedures. The BREED factor was 'forced' into Models 3-6. $\mathrm{N}=$ number of groups means used in each analysis. Some models are given for both unweighted and weighted data. Models 5 and 6 involve the same parameters but using either (Model 5) the same 45 samples used in models 1-4 or (Model 6) all the data available for these parameters.

\begin{tabular}{|c|c|c|c|c|c|c|c|c|c|c|}
\hline Model & Breed & Weighted & Constant & $\begin{array}{c}\text { MUN } \\
(\mathrm{mmol} / \mathrm{L})\end{array}$ & WSC/CP & Breed (JF) & $\mathbf{N}$ & $\begin{array}{c}\text { Adj. } R^{2} \\
(\%)\end{array}$ & AIC & $p$ \\
\hline 1 & No & No & $\begin{array}{c}0.3326 \\
(0.0408)\end{array}$ & $\begin{array}{l}-0.0102 \\
(0.0019)\end{array}$ & $\begin{array}{c}0.0297 \\
(0.0204)\end{array}$ & - & 45 & 66.6 & 47.03 & $<0.001$ \\
\hline 2 & No & Yes & $\begin{array}{c}0.3238 \\
(0.0436)\end{array}$ & $\begin{array}{l}-0.0096 \\
(0.0020)\end{array}$ & $\begin{array}{c}0.0381 \\
(0.0225)\end{array}$ & - & 45 & 71.1 & 47.28 & $<0.001$ \\
\hline 3 & Yes & No & $\begin{array}{c}0.3402 \\
(0.0428)\end{array}$ & $\begin{array}{l}-0.0104 \\
(0.0020)\end{array}$ & $\begin{array}{c}0.0292 \\
(0.0205)\end{array}$ & $\begin{array}{l}-0.0082 \\
(0.0126)\end{array}$ & 45 & 66.1 & 48.00 & $<0.001$ \\
\hline 4 & Yes & Yes & $\begin{array}{c}0.3215 \\
(0.0475)\end{array}$ & $\begin{array}{l}-0.0095 \\
(0.0022)\end{array}$ & $\begin{array}{c}0.0385 \\
(0.0230)\end{array}$ & $\begin{array}{c}0.0018 \\
(0.0137)\end{array}$ & 45 & 70.4 & 48.26 & $<0.001$ \\
\hline 5 & Yes & No & $\begin{array}{c}0.3943 \\
(0.0199)\end{array}$ & $\begin{array}{l}-0.0124 \\
(0.0014)\end{array}$ & - & $\begin{array}{c}-0.0088 \\
(0.0128)\end{array}$ & 45 & 65.3 & 47.98 & $<0.001$ \\
\hline 6 & Yes & No & $\begin{array}{c}0.3591 \\
(0.0157)\end{array}$ & $\begin{array}{l}-0.0105 \\
(0.0011)\end{array}$ & - & $\begin{array}{c}0.0018 \\
(0.0104)\end{array}$ & 67 & 56.8 & - & $<0.001$ \\
\hline
\end{tabular}

Table 6. Models (coefficients (95\% CI)) relating NUE of ryegrass-fed Friesian and Jersey $\times$ Friesian cows to the dietary parameter WSC /CP and animal-based parameter MUN. Models are given for all the available data and each breed separately. $\mathrm{S}$ is the standard error of the observations.

\begin{tabular}{|c|c|c|c|c|c|c|c|}
\hline \multicolumn{8}{|c|}{ Equation of Form: NUE $=a+b(\mathrm{WSC} / \mathrm{CP})$} \\
\hline Model & Breed & $a$ & $b$ & & $\mathbf{N}$ & $\mathbf{S}$ & $p$ \\
\hline 7 & All & $\begin{array}{c}0.1324 \\
(0.093-0.172)\end{array}$ & $\begin{array}{c}0.1087 \\
(0.073-0.144)\end{array}$ & & 45 & 0.052 & $<0.001$ \\
\hline 8 & $\mathrm{~F}$ & $\begin{array}{c}0.1700 \\
(0.151-0.189)\end{array}$ & $\begin{array}{c}0.0665 \\
(0.049-0.084)\end{array}$ & & 22 & 0.021 & $<0.001$ \\
\hline 9 & $\mathrm{~J}-\mathrm{F}$ & $\begin{array}{c}0.0195 \\
(-0.070-0.109)\end{array}$ & $\begin{array}{c}0.2144 \\
(0.136-0.293)\end{array}$ & & 23 & 0.058 & $<0.001$ \\
\hline \multicolumn{8}{|c|}{ Equation of Form: NUE $=a+b c^{\mathrm{MUN}}$} \\
\hline & & $a$ & $b$ & $c$ & $\mathbf{N}$ & $\mathbf{S}$ & $p$ \\
\hline 10 & All & $\begin{array}{c}0.2001 \\
(0.187-0.211)\end{array}$ & $\begin{array}{c}0.7000 \\
(0.502-1.003)\end{array}$ & $\begin{array}{c}0.7085 \\
(0.645-0.769)\end{array}$ & 68 & 0.028 & $<0.001$ \\
\hline 11 & $\mathrm{~F}$ & $\begin{array}{c}0.1906 \\
(-0.087-0.212)\end{array}$ & $\begin{array}{c}0.2506 \\
(-0.051-0.559)\end{array}$ & $\begin{array}{c}0.8393 \\
(0.704-0.979)\end{array}$ & 35 & 0.022 & $<0.001$ \\
\hline 12 & $\mathrm{~J}-\mathrm{F}$ & $\begin{array}{c}0.1896 \\
(0.163-0.210)\end{array}$ & $\begin{array}{c}0.6950 \\
(0.486-1.053)\end{array}$ & $\begin{array}{c}0.7306 \\
(0.647-0.807)\end{array}$ & 33 & 0.031 & $<0.001$ \\
\hline
\end{tabular}

Examination of all models weighted and unweighted, with and without BREED, shows little difference in coefficients between models. In addition, plots of predicted NUE values against observed NUE values (Figure 2) revealed a relatively equal distribution of residuals from the line of best fit, except for one or two groups of Friesian cows that had lower than predicted NUE values and a cluster of Jersey $\times$ Friesian groups that had higher NUE values than predicted by the models.

The negative relationship between NUE and MUN was best described by an asymptotic curve (Table 6; Figure 3). Unlike WSC/CP, an all-inclusive model (Model 10) produced a relatively low value of $\mathrm{S}$ of 0.028 (Table 6 ), and the $95 \%$ CIs for all the model parameters overlapped for the individual breed models and the model based on both breeds. The separate models for the Friesian and the Jersey $\times$ Friesian cows appeared to differ in only one aspect-coefficient $b$ when the equation was written as NUE $=a+b c^{\mathrm{MUN}}$. This coefficient partially dictates the intercept of the line on the $y$-axis $(a+b$, i.e., the NUE when MUN $=0$ ) and was $0.25 \mathrm{~g} / \mathrm{g}$ for Friesian and $0.69 \mathrm{~g} / \mathrm{g}$ for Jersey $\times$ Friesian cows. 

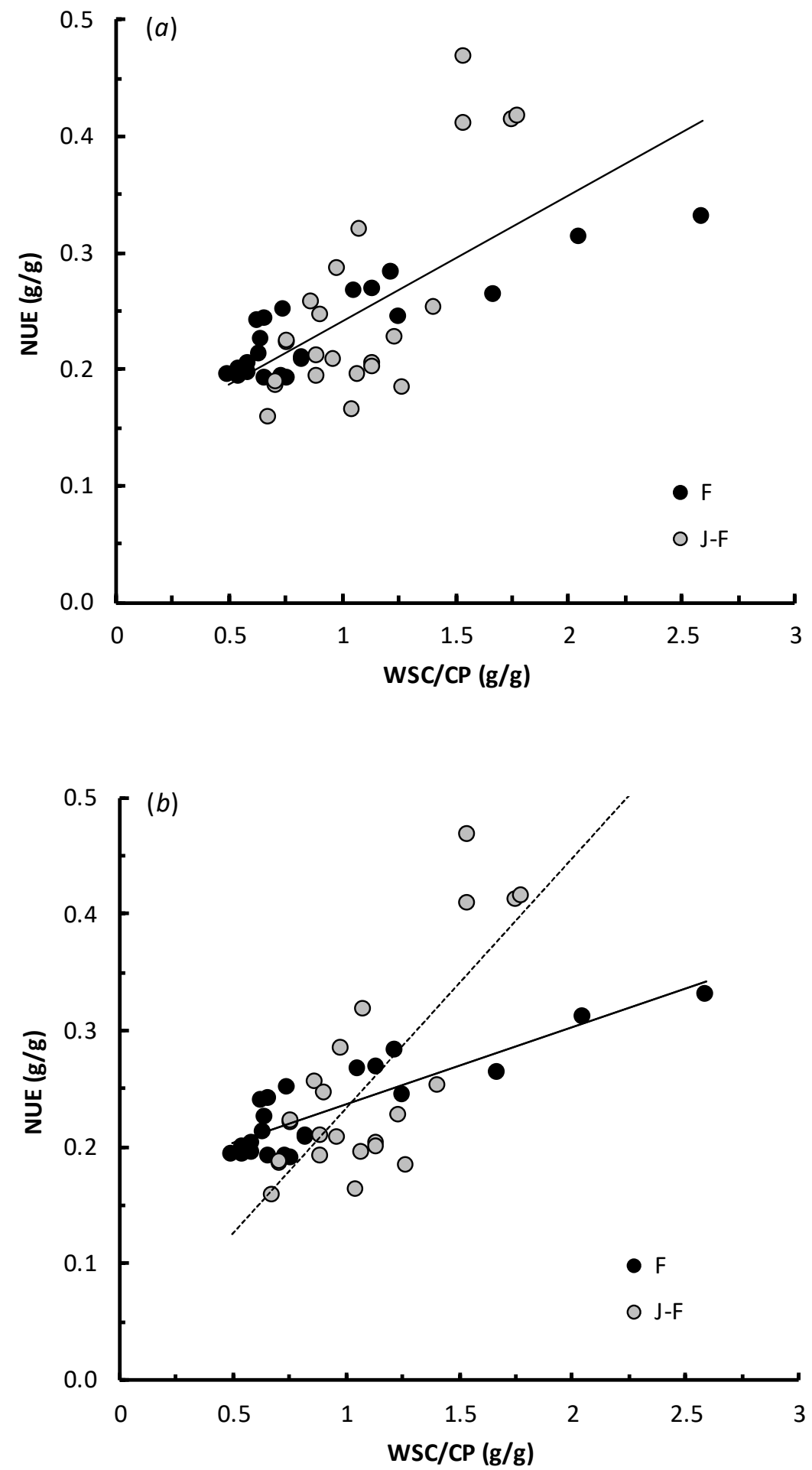

Figure 1. Linear relationships between NUE and dietary WSC/CP ratio for groups of ryegrass-fed Friesian $(\mathrm{N}=22)$ and Jersey $\times$ Friesian $(\mathrm{N}=23)$ cows: $(\mathbf{a})$ shows the overall line of best fit (Model 7; Table 6) and (b) shows separate regression models for both breeds (Models 8 and 9; Table 6). 

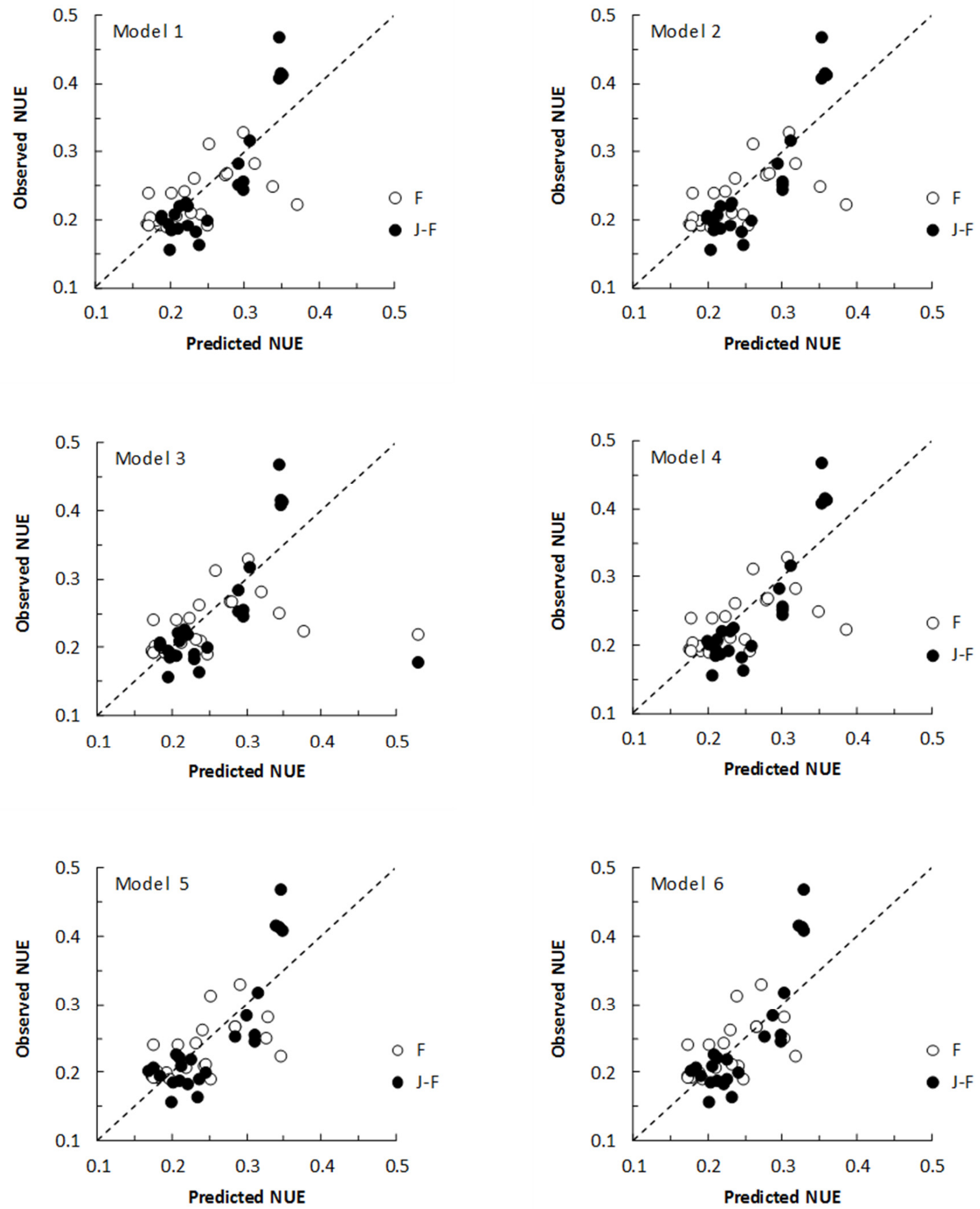

Figure 2. Plots of predicted NUE values vs. observed group NUE scores for Friesian and Jersey $\times$ Friesian cows from models 1-6 produced via all subset regression procedures (Table 5). The dotted line represents the line of the perfect fit. ( $\mathrm{N}=45$; only those groups for which NUE, WS/CP, and MUN data were all available and have been included). 

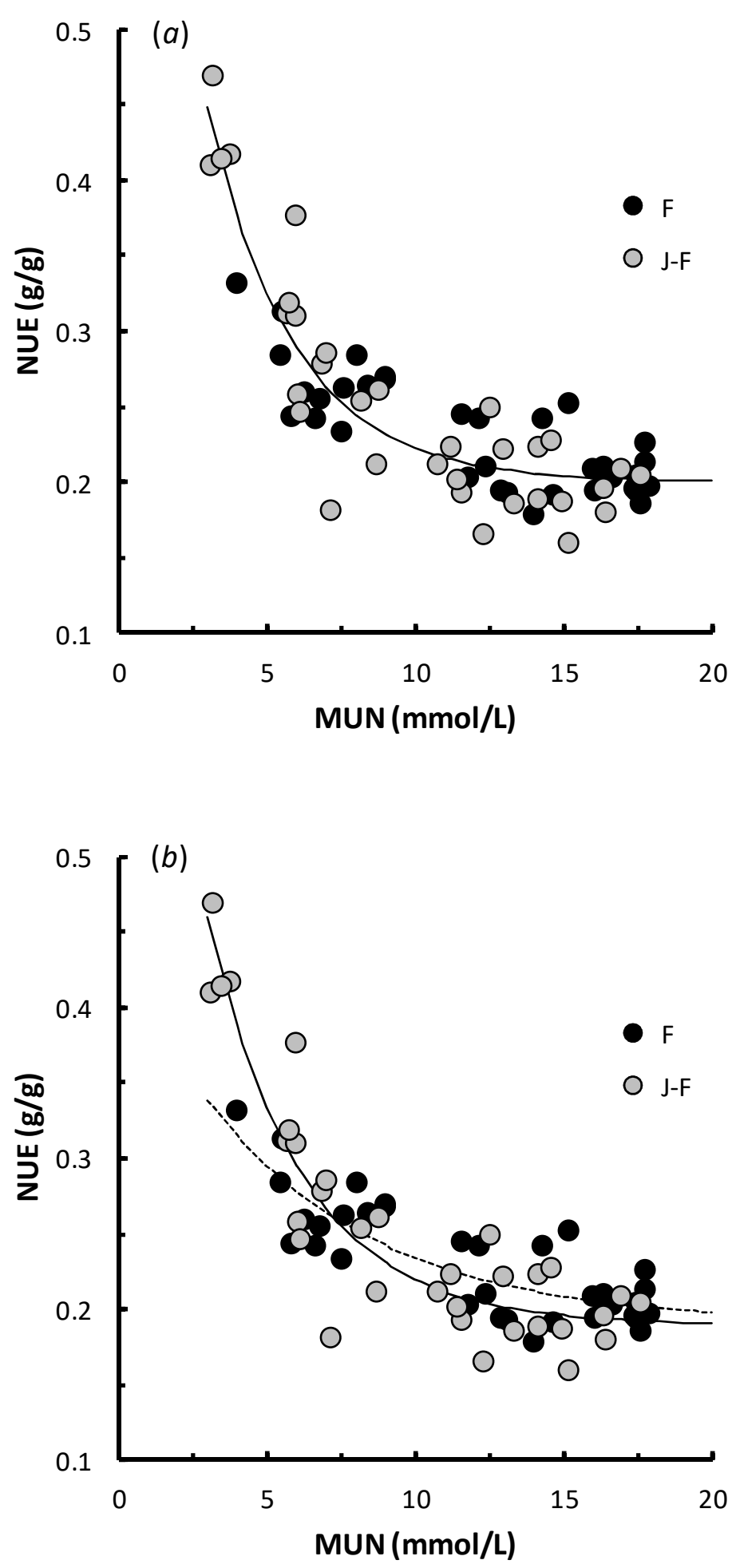

Figure 3. Asymptotic relationships between NUE and MUN for groups of ryegrass-fed Friesian $(\mathrm{N}=35)$ and Jersey $\times$ Friesian $(\mathrm{N}=33)$ cows: (a) shows the overall line of best fit (Model 10; Table 6) and (b) shows separate regression models for both breeds (Models 11 and 12; Table 6).

\subsection{Model Evaluation}

When evaluating these models with newly obtained data for both breeds, the MAE and RMSE were lesser when using the MUN-based model than the models based on WSC/CP (Table 7). This translated to standardised errors (MRAE and NRMSE) of approximately $11.5-18.5 \%$ when using the WSC /CP equations and approximately $7.5-13.5 \%$ when using 
the MUN model. Although the predicted and observed values of NUE were highly correlated when using the breed-specific linear equations based on WSC $/ \mathrm{CP}$, concordance was low, especially for Friesians (Table 7; Figure 4). Conversely, concordance was higher for both breeds when using the model based on MUN (Table 7; Figure 4).
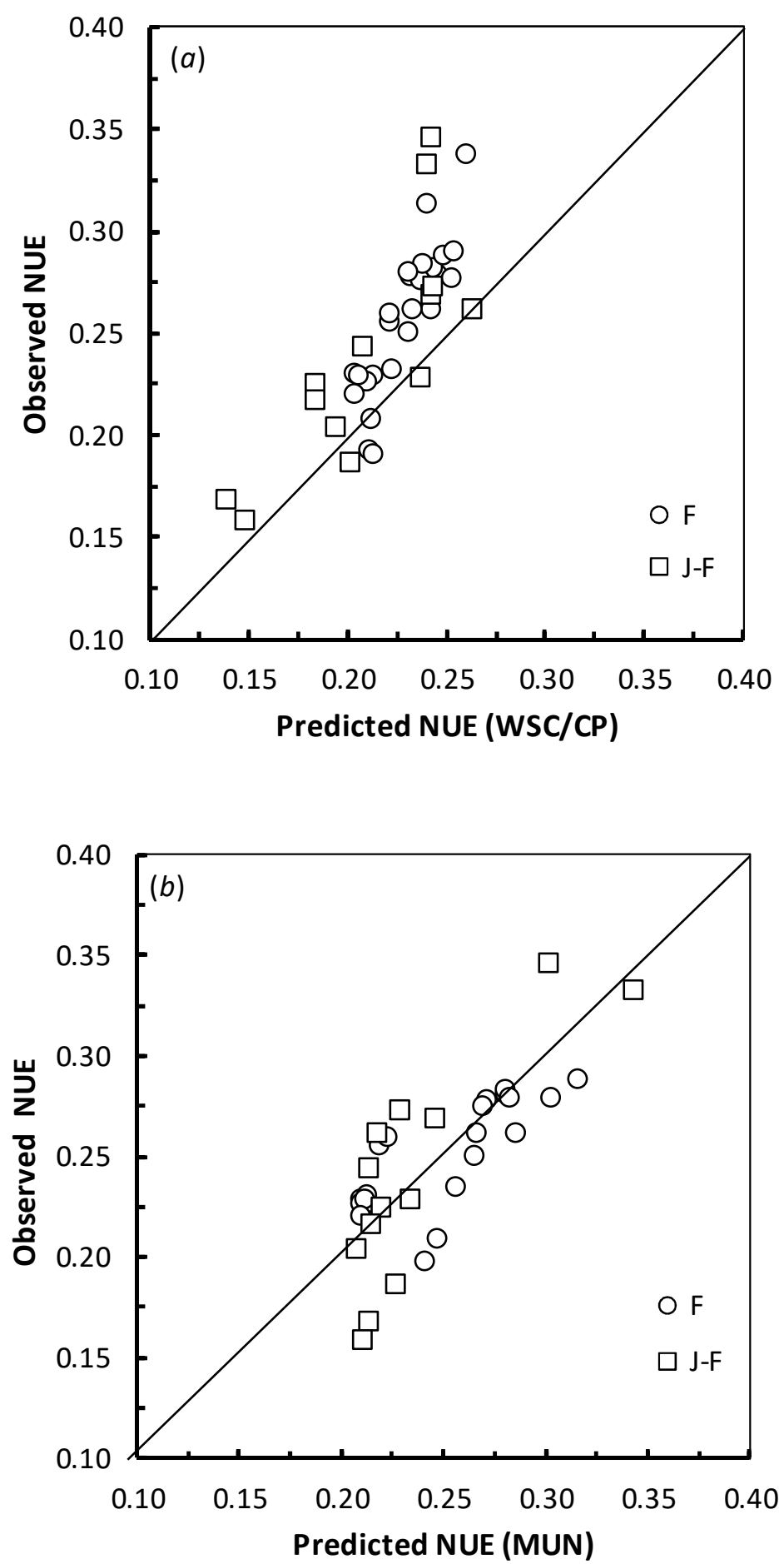

Figure 4. Correspondence of observed NUE values with those predicted using models based on (a) WSC /CP (Models 7 and 8; Table 6) and (b) MUN (Model 10; Table 6) for groups of Friesian ( $=27)$ and Jersey $\times$ Friesian $(\mathrm{N}=13)$ cows not used in model development. The straight line indicates one-to-one correspondence between observed and predicted values. 
Table 7. Measures of deviation between observed and predicted values of NUE for data obtained from studies not used in model development: mean absolute error (MAE), root mean square error (RMSE), mean relative absolute error (MRAE), and normalised root mean square error (NRMSE). Relationships between observed and predicted values of NUE are illustrated using Pearson's correlation coefficient and Lin's concordance coefficient. Friesians $N=27$; Jersey $\times$ Friesian $N=13$. Model numbers refer to the equations presented in Table 6 .

\begin{tabular}{|c|c|c|c|c|}
\hline Predictor & Models & Measure of Model Fit & $\mathbf{F}$ & $J-F$ \\
\hline WSC/CP & $8 \& 9$ & MAE & 0.031 & 0.033 \\
\hline \multirow{5}{*}{\multicolumn{2}{|c|}{$\mathrm{NUE}=a+b(\mathrm{WSC} / \mathrm{CP})$}} & RMSE & 0.035 & 0.045 \\
\hline & & MRAE (\%) & 11.57 & 12.81 \\
\hline & & NRMSE (\%) & 13.77 & 18.67 \\
\hline & & Correlation & 0.870 & 0.796 \\
\hline & & Concordance & 0.459 & 0.630 \\
\hline MUN & 10 & MAE & 0.018 & 0.027 \\
\hline \multirow{5}{*}{\multicolumn{2}{|c|}{$\mathrm{NUE}=a+b c^{\mathrm{MUN}}$}} & RMSE & 0.022 & 0.033 \\
\hline & & MRAE (\%) & 7.74 & 12.26 \\
\hline & & NRMSE (\%) & 8.91 & 13.64 \\
\hline & & Correlation & 0.748 & 0.811 \\
\hline & & Concordance & 0.729 & 0.764 \\
\hline
\end{tabular}

\section{Discussion}

\subsection{The Database, Rank Correlations, and Simple Linear Regression Models}

The dataset covered a wide range of MUN values; some are high values, possibly due to dietary ryegrass that were fertilised with urea as part of the growth-promoting strategy. The average MUN concentration was slightly higher for Friesians than Jersey $\times$ Friesians (12.2 vs. $10.1 \mathrm{mmol} / \mathrm{L}$, respectively). Similarly, previous reports [14,43] reported higher MUN concentrations in the milk of Holsteins in comparison with Jersey cows. In addition, Jonker et al. (1999) [44] suggested factors such as body weight, milk production, milk protein, and fat concentration, and $\mathrm{N}$ intake contribute to breeding differences in MUN concentrations.

According to the rank correlations of parameters with NUE for grazing Friesian and Jersey $\times$ Friesian dairy cows, many of the parameters had strong, significant rank correlations with NUE, indicating that they are potentially useful indicators for a simplistic assignment of NUE ranking. High absolute values for $R^{2}$ were found for dietary parameters (e.g., N, CP, ME/CP, and WSC/CP), animal-based parameters (e.g., NI, MUN), and some derived measures (e.g., $\mathrm{MN} / \mathrm{UN}, \mathrm{UN} / \mathrm{NI}$ ). Dietary parameters based on fibre content (ADF, NDF) were not strongly related to NUE. A similar weak correlation between NUE and dietary fibre content was shown in the study of Pacheco et al. [6]. Parameters based on dietary ME were not considered further in this study due to the low number of data points for Friesians $(n=9)$.

The high correlations between NUE and WSC/CP for dairy cows on the pasture-based systems have been described previously [6,45]. Edwards et al. [45] reported that increasing WSC concentration could correct the imbalance between the energy and protein supply in the rumen. This increase in WSC concentration would improve the capture of ruminal ammonia into microbial protein and influence the supply of absorbed amino acids for milk protein production [46]. Furthermore, ruminal carbohydrate digestibility and efficiency of ruminal $\mathrm{N}$ fermentation can only affect MUN indirectly through either an increase in milk $\mathrm{N}$ excretion, a decrease in $\mathrm{N}$ intake, or an increase in faecal $\mathrm{N}$ with a net result of reducing urinary $\mathrm{N}$ excretion [10].

However, a positive relationship between NUE and WSC is not always observed, for example, in cows offered a high CP diet [29]. Further, Pacheco et al. [6] and Edwards et al. [45] reported WSC/CP of 0.75 and 0.7 , respectively, as the breakpoints above 
which NUE was affected. In the current study, most of the reported values for the WSC/CP were above the suggested breakpoint, ranging from 0.5 to 2.6 for Friesians and from 0.7 to 1.8 for the Jersey $\times$ Friesian cows, which may explain the significant relationship between NUE and WSC/CP in the current data set. Therefore, the linear regression models developed using WSC/CP (Models 8 and 9) should be treated with caution, as additional validation is required for cows fed pasture with WSC/CP below 0.7 .

Of all individual animal factors, MUN showed consistently the highest $R^{2}$ values $(>63 \%$ ) for both breeds. This is in agreement with the study of Broderick and Clayton [8], who reported a strong relationship between the NUE and MUN ( $R^{2}=63 \%$ ) for cows offered balanced rations under a confinement system. It is important to note that NUE was under-predicted when Broderick and Clayton's [8] model was evaluated using the current data set. This suggests that predictive models for NUE using MUN may only be of value for specific management systems (e.g., pasture vs. mixed rations) and/or specific breeds, such as Jersey $\times$ Friesian. Kauffman and St-Pierre [10] reported that breed had a significant effect on $\mathrm{N}$ intake because the Holstein cows had a higher DMI than the Jersey cows. The effect of breed on the UN-MUN relationship was considerable but fully explained by BW differences as a scale factor. Rodriguez et al. [14] reported a significant effect of breed on MUN, with milk from Holstein cows $40 \%$ higher in MUN than milk from Jersey cows. To the best of our knowledge, no published studies in the literature reported Jersey $\times$ Friesian differences in NUE and MUN levels. This is an area that requires more research.

The highest adjusted $R^{2}$ obtained was $83.9 \%$ for the derived measure MN/UN ratio. However, this is not surprising, as the calculation for NUE also has MN as the numerator and may not reflect a biological relationship. In addition, $\mathrm{MN}$ and $\mathrm{UN}$ are challenging to measure, particularly for a large number of cows under grazing conditions. Therefore, the $\mathrm{MN} / \mathrm{UN}$ ratio was considered an inappropriate and impractical parameter to include in predictive models for NUE. Similarly, NI of grazing cows is difficult to measure and is also used in the calculation of NUE, and thus, it was not considered further.

\subsection{All Subset Regression Analyses and Multiple Regression Models}

Despite the ranking and predictive ability of the models, using multiple regression models did not improve the prediction of NUE, compared with the regressions using a single predictor. For example, the simple regression using MUN to predict NUE produced an adjusted $R^{2}$ of $77 \%$ and $66 \%$ for the Friesian and Jersey $\times$ Friesian, respectively. These adjusted $R^{2}$ are close to the value of $70 \%$ for Model 4, in which multiple parameters (MUN, WSC /CP, and breed) were used to predict NUE. This result implies there is no need to use multiple factor models to predict NUE of grazing Friesian or Jersey $\times$ Friesian dairy cows Instead, models using a single parameter (e.g., MUN or WSC/CP) produced a similar predictive ability of NUE prediction, which is important for industry application.

\subsection{Practical Parameters: The Relationships of NUE with WSC/CP and MUN}

Using separate models (Models 8 and 9) for different breeds may be considered a valuable way of accounting for the variation between animals, mainly when dietary factors are used to predict NUE [7]. Although separate models are required for the two breeds in our study, further research would be required to examine whether separate models are required for all breeds. In New Zealand, where the significant dairy herds are limited to only a few breeds (Jerseys, Friesians, Holsteins, and their crosses), developing separate models for each breed might not be too onerous a task.

The asymptotes of all three NUE $v$ MUN models (Models 10-12) are $\approx 0.2$, which suggests there is some point (approximately MUN $=10 \mathrm{mmol} / \mathrm{L}$ ) at which NUE becomes less responsive to any further increase in MUN. The corresponding NUE value of approximately $20 \%$ is in good agreement with the floor of $19 \%$ reported for dairy cows grazing fresh herbage [29]. MUN may not be useful for differentiating NUE at high levels of N intake $[8,9]$, possibly because higher levels of $\mathrm{N}$ are being excreted in the urine rather than being used for milk protein production $[5,47]$. Therefore, the alternative biomarker should 
be explored to indicate NUE in high N intake conditions [48]. Further, Castillo et al. [47] reported that urine is the main route for $\mathrm{N}$ excretion when $\mathrm{N}$ intake of average yielding dairy cows exceeds $400 \mathrm{~g} \mathrm{~N} / \mathrm{cow} / \mathrm{d}$. On the other hand, when $\mathrm{N}$ is limiting, the proportion of urea recycled back to the gut increases to ensure adequate $\mathrm{N}$ is available to meet the requirements for maintenance and production $[49,50]$. Thus, an $\mathrm{N}$ limiting diet results in a reduction in MUN and a corresponding increase in NUE. Nevertheless, the current results suggest that when efforts are being made to improve NUE, MUN is a valuable, easily obtained monitoring tool for NUE, particularly with MUN values below $10 \mathrm{mmol} / \mathrm{L}$.

\subsection{Model Evaluation}

This observed higher concordance for both breeds when using the model based on MUN may support the previous suggestion that WSC/CP is a dietary measurement and does not take account of variation in $\mathrm{N}$ metabolism between and within breeds. In contrast, MUN may reflect the differences in $\mathrm{N}$ metabolism between breeds and dietary effects. In addition, the chemical composition of pasture is subjected to diurnal fluctuations [51,52], and therefore, that time of sampling may affect the accuracy of NUE predictions when using WSC/CP. Overall, the result indicates that MUN [Model 10] should be used to predict NUE for grazing dairy cows.

\section{Conclusions}

Milk urea nitrogen and dietary WSC/CP were the best and most practical parameters to predict NUE for grazing dairy cows. Using WSC/CP to predict NUE, separate models need to be used for different cow breeds. Overall, the model evaluation process indicated that the model using MUN as the independent variable resulted in predicted values of NUE that were closer to the observed NUE than did the models using WSC/CP. Additional validation of these models using other herds of dairy cows from the same and other geographic regions and of the same and other breeds is required before this can be used as a valid index to differentiate the NUE of all dairy cows under pasture-based feeding.

Author Contributions: Data collection, W.A., S.H., R.J.D., A.C., G.R.E. and L.C.; data analysis, S.H., G.Z. and L.C.; draft and revision of manuscript, W.A., O.A.-M., R.J.D., A.C., G.Z., S.T., G.R.E. and L.C. All authors have read and agreed to the published version of the manuscript.

Funding: This research received no external funding.

Institutional Review Board Statement: Not applicable.

Informed Consent Statement: Not applicable.

Data Availability Statement: The data presented in this study.

Acknowledgments: We acknowledge the constructive comments provided by editors and reviewers to improve this manuscript.

Conflicts of Interest: The authors declare no conflict of interest.

\section{References}

1. Nennich, T.D.; Harrison, J.H.; Van Wieringen, L.M.; St-pierre, N.R.; Kincaid, R.L.; Wattiaus, M.A.; Davidson, D.L.; Block, E. Prediction and evaluation of urine and urinary nitrogen and mineral excretion from dairy cattle. J. Dairy Sci. 2006, 89, 353-364. [CrossRef]

2. Keim, J.P.; Anrique, R. Nutritional Strategies to Improve Nitrogen use Efficiency by Grazing Dairy Cows. Chil. J. Agric. Res. 2011, 71, 623-633. [CrossRef]

3. Bryant, R.H.; Walpot, V.; Dalley, D.E.; Gibbs, S.J.; Edwards, G.R. Manipulating dietary N in perennial ryegrass pastures to reduce $\mathrm{N}$ losses in dairy in spring. In Proceedings of the 4th Australasian Dairy Science Symposium, Lincoln, New Zealand, 31 August-2 September 2010; pp. 97-100.

4. Johnson, A.; Reed, K.; Kebreab, E. Short communication: Evaluation of nitrogen excretion equations from cattle. J. Dairy Sci. 2016, 99, 7669-7678. [CrossRef]

5. Pacheco, D.; Waghorn, G. Dietary nitrogen—Definitions, digestion, excretion and consequences of excess for grazing ruminants. N. Z. Grassl. Assoc. 2008, 70, 107-116. [CrossRef] 
6. Pacheco, D.; Burke, J.L.; Cosgrove, G.P. An empirical model to estimate efficiency of nitrogen utilisation in cows grazing fresh forages. In Proceedings of the Australasian Dairy Science Symposium, Melbourne, VA, Australia, 18-20 September 2007; pp. 409-416.

7. Cheng, L.; Woodward, S.L.; Dewhurst, R.J.; Zhou, H.; Edwards, G.R. Nitrogen partitioning, energy use efficiency and isotopic fractionation measurements from cows differing in genetic merit fed low-quality pasture in late lactation. Anim. Prod. Sci. 2014, 54, 1651-1656. [CrossRef]

8. Broderick, G.A.; Clayton, M.K. A Statistical Evaluation of Animal and Nutritional Factors Influencing Concentrations of Milk Urea Nitrogen. J. Dairy Sci. 1997, 80, 2964-2971. [CrossRef]

9. Jonker, J.; Kohn, R.; Erdman, R. Using Milk Urea Nitrogen to Predict Nitrogen Excretion and Utilization Efficiency in Lactating Dairy Cows. J. Dairy Sci. 1998, 81, 2681-2692. [CrossRef]

10. Kauffman, A.; St-Pierre, N. The Relationship of Milk Urea Nitrogen to Urine Nitrogen Excretion in Holstein and Jersey Cows. J. Dairy Sci. 2001, 84, 2284-2294. [CrossRef]

11. Beatson, P.R.; Meier, S.; Cullen, N.G.; Eding, H. Genetic variation in milk urea nitrogen concentration of dairy cattle and its implications for reducing urinary nitrogen excretion. Animal 2019, 13, 2164-2171. [CrossRef]

12. Ariyarathne, H.B.P.C.; Correa-Luna, M.; Blair, H.; Garrick, D.; Lopez-Villalobos, N. Can nitrogen excretion of dairy cows be reduced by genetic selection for low milk urea nitrogen concentration? Animals 2021, 11, 737-755. [CrossRef] [PubMed]

13. Ferguson, J.D.; Thomson, N.; Slesser, D.; Burris, D. Pennsylvania DHIA milk urea testing. J. Dairy Sci. $1997,80,161$.

14. Rodríguez, L.; Stallings, C.; Herbein, J.; McGilliard, M. Effect of Degradability of Dietary Protein and Fat on Ruminal, Blood, and Milk Components of Jersey and Holstein Cows. J. Dairy Sci. 1997, 80, 353-363. [CrossRef]

15. Carruthers, V.R.; Neil, P.G. Milk production and ruminal metabolites from cows offered two pasture diets supplemented with non-structural carbohydrate. N. Z. J. Agric. Res. 1997, 40, 513-521. [CrossRef]

16. Mackle, T.R.; Bryant, A.M.; Petch, S.F.; Hooper, R.J.; Auldist, M.J. Variation in the composition of milk protein from pasture-fed dairy cows in late lactation and the effect of grain and silage supplementation. N. Z. J. Agric. Res. 1999, 42, 147-154. [CrossRef]

17. Mackle, T.; Kay, J.; Auldist, M.; McGibbon, A.; Philpott, B.; Baumgard, L.; Bauman, D. Effects of Abomasal Infusion of Conjugated Linoleic Acid on Milk Fat Concentration and Yield from Pasture-Fed Dairy Cows. J. Dairy Sci. 2003, 86, 644-652. [CrossRef]

18. Pacheco, D.; Lowe, K.; Burke, J.L.; Cosgrove, G.P. Urinary nitrogen excretion from cows at different stage of lactation grazing different ryegrass cultivars during spring or autumn. Proc. N. Z. Soc. Anim. Prod. 2009, 69, 96-200.

19. Higgs, R.J.; Cosgrove, G.P.; Burke, J.L.; Lane, G.A.; Pacheco, D.; Fraser, K.; Death, A.F.; Ford, J.L. Effect of white clover containing either high or low concentrations of water-soluble carbohydrate on metabolic indicators of protein degradation in the rumen of dairy cows. Proc. N. Z. Soc. Anim. Prod. 2009, 70, 23-28.

20. Pacheco, D.; Burke, J.L.; Cosgrove, G.P. The effect of different methods of presenting ryegrass and white clover diets on nitrogen utilisation by cows. In Proceedings of the 4th Australasian Dairy Science Symposium, Lincoln, New Zealand, 31 August-2 September 2010; pp. 101-105.

21. Mackle, T.R.; Parr, C.R.; Bryant, A.M. Nitrogen fertiliser effects on milk yield and composition, pasture intake, nitrogen and energy partitioning, and rumen fermentation parameters of dairy cows in early lactation. N. Z. J. Agric. Res. 1996, 39, 341-356. [CrossRef]

22. Carruthers, V.R.; Neil, P.G.; Dalley, D.E. Effect of altering the non-structural: Structural carbohydrate ratio in a pasture diet on milk production and ruminal metabolites in cows in early and late lactation. Anim. Sci. 1997, 64, 393-402. [CrossRef]

23. Harris, S.L.; Auldist, M.J.; Clark, D.A.; Jansen, E.B.L. Effects of white clover content in the diet on herbage intake, milk production and milk composition of New Zealand dairy cows housed indoors. J. Dairy Res. 1998, 65, 389-400. [CrossRef] [PubMed]

24. Kolver, E.S.; Aspin, P.W. Supplemental fumarate did not influence milk solids or methane production from dairy cows fed high quality pasture. Proc. N. Z. Soc. Anim. Prod. 2006, 66, 409-415.

25. Allen, M.E. The Effects of Gibberellic Acid and Time of Grazing on Nitrogen Partitioning in Dairy Cows Grazing Perennial Ryegrass Pastures. Master's Thesis, Lincoln University, Lincoln, New Zealand, 2010.

26. Woodward, S.L.; Waghorn, G.C.; Bryant, M.A.; Mandok, K. Are high breeding worth index cows more feed conversion efficient and nitrogen use efficient? Proc. N. Z. Soc. Anim. Prod. 2011, 71, 109-113.

27. Engellbrecht, K.S. Rumen digestion, intake, milk production and nitrogen partitioning of dairy cows grazing simple vs diverse pasture swards at high and low pasture allowance. Master's Thesis, Lincoln University, Lincoln, New Zealand, 2012.

28. Taweel, H.; Tas, B.; Smit, H.; Elgersma, A.; Dijkstra, J.; Tamminga, S. Effects of feeding perennial ryegrass with an elevated concentration of water-soluble carbohydrates on intake, rumen function and performance of dairy cows. Anim. Feed Sci. Technol. 2005, 121, 243-256. [CrossRef]

29. Tas, B.; Taweel, H.; Smit, H.; Elgersma, A.; Dijkstra, J.; Tamminga, S. Utilisation of N in perennial ryegrass cultivars by stall-fed lactating dairy cows. Livest. Sci. 2006, 100, 159-168. [CrossRef]

30. Abrahamse, P.A.; Tamminga, S.; Dijkstra, J. Effect of daily movement of dairy cattle to fresh grass in morning or afternoon on intake, grazing behaviour, rumen fermentation and milk production. J. Agric. Sci. 2009, 147, 721-730. [CrossRef]

31. Wims, C.; McEvoy, M.; Delaby, L.; Boland, T.; O'Donovan, M. Effect of perennial ryegrass (Lolium perenne L.) cultivars on the milk yield of grazing dairy cows. Animal 2013, 7, 410-421. [CrossRef] [PubMed]

32. Clark, C.; McLeod, K.; Glassey, C.; Gregorini, P.; Costall, D.; Betteridge, K.; Jago, J. Capturing urine while maintaining pasture intake, milk production, and animal welfare of dairy cows in early and late lactation. J. Dairy Sci. 2010, 93, 2280-2286. [CrossRef] 
33. Totty, V.; Greenwood, S.; Bryant, R.; Edwards, G. Nitrogen partitioning and milk production of dairy cows grazing simple and diverse pastures. J. Dairy Sci. 2013, 96, 141-149. [CrossRef]

34. Bryant, R.H.; Dalley, D.E.; Gibbs, J.; Edwards, G. Effect of grazing management on herbage protein concentration, milk production and nitrogen excretion of dairy cows in mid-lactation. Grass Forage Sci. 2013, 69, 644-654. [CrossRef]

35. Al-Marashdeh, O.; Greenwood, S.L.; Hodge, S.; Edwards, G.R. The effects of feeding maize silage at different times prior to a herbage meal on dry matter intake, milk solids production and nitrogen excretion in late-lactation dairy cows. Proc. N. Z. Soc. Anim. Prod. 2015, 75, 140-144.

36. Al-Marashdeh, O.; Gregorini, P.; Greenwood, S.L.; Edwards, G. The effect of feeding maize silage $1 \mathrm{~h}$ or $9 \mathrm{~h}$ before the herbage meal on dry matter intake, milk production, nitrogen partitioning and rumen function of lactating dairy cows. Anim. Prod. Sci. 2016, 56, 2004-2013. [CrossRef]

37. Al-Marashdeh, O.; Gregorini, P.; Edwards, G. Effect of time of maize silage supplementation on herbage intake, milk production, and nitrogen excretion of grazing dairy cows. J. Dairy Sci. 2016, 99, 7123-7132. [CrossRef]

38. Payne, R.A. Guide to Regression, Nonlinear and Generalized Linear Models in GenStat, 16th ed.; VSN International Ltd.: Hemel Hempstead, UK, 2013.

39. Miller, G.A.; Chapman, J.P. Misunderstanding analysis of covariance. J. Abnorm. Psychol. 2001, 110, 40-48. [CrossRef]

40. Jamieson, J. Analysis of covariance (ANCOVA) with difference scores. Int. J. Psychophysiol. 2004, 52, 277-283. [CrossRef]

41. Spiess, A.-N.; Neumeyer, N. An evaluation of R2 as an inadequate measure for nonlinear models in pharmacological and biochemical research: A Monte Carlo approach. BMC Pharmacol. 2010, 10, 6. [CrossRef] [PubMed]

42. Lin, L.I.-K. A Concordance Correlation Coefficient to Evaluate Reproducibility. Biometrics 1989, 45, 255. [CrossRef]

43. Johnson, R.; Young, A. The Association Between Milk Urea Nitrogen and DHI Production Variables in Western Commercial Dairy Herds. J. Dairy Sci. 2003, 86, 3008-3015. [CrossRef]

44. Jonker, J.; Kohn, R.; Erdman, R. Milk Urea Nitrogen Target Concentrations for Lactating Dairy Cows Fed According to National Research Council Recommendations. J. Dairy Sci. 1999, 82, 1261-1273. [CrossRef]

45. Edwards, G.R.; Parsons, A.J.; Rasmussen, S. High sugar ryegrasses for dairy systems. Meeting the Challenges for Pasture-Based Dairying. In Proceedings of the Australasian Dairy Science Symposium, Melbourne, VA, Australia, 2007; 2007; pp. 307-334.

46. Miller, L.A.; Moorby, J.M.; Davies, D.R.; Humphreys, M.O.; Scollan, N.D.; Macrae, J.C.; Theodorou, M.K. Increased concentration of water-soluble carbohydrate in perennial ryegrass (Lolium perenne L.): Milk production from late-lactation dairy cows. Grass Forage Sci. 2001, 56, 383-394. [CrossRef]

47. Castillo, A.R.; Kebreab, E.; Beever, D.E.; France, J. A review of efficiency of nitrogen utilisation in lactating dairy cows and its relationship with environmental pollution. J. Anim. Feed Sci. 2000, 9, 1-32. [CrossRef]

48. Cheng, L.; Sheahan, A.J.; Gibbs, S.J.; Rius, A.; Kay, J.K.; Meier, S.; Edwards, G.R.; Dewhurst, R.; Roche, J.R. Technical note: Nitrogen isotopic fractionation can be used to predict nitrogen-use efficiency in dairy cows fed temperate pasture. J. Anim. Sci. 2013, 91, 5785-5788. [CrossRef]

49. Røjen, B.; Lund, P.; Kristensen, N.B. Urea and short-chain fatty acids metabolism in Holstein cows fed a low-nitrogen grass-based diet. Animal 2008, 2, 500-513. [CrossRef] [PubMed]

50. Krehbiel, C.R.; Ferrell, C.L.; Freetly, H.C. Effects of frequency of supplementation on dry matter intake and net portal and hepatic flux of nutrients in mature ewes that consume low-quality forage. J. Anim. Sci. 1998, 76, 2464-2473. [CrossRef]

51. Orr, R.; Rutter, M.; Penning, P.D.; Rook, A.J. Matching grass supply to grazing patterns for dairy cows. Grass Forage Sci. 2001, 56, 352-361. [CrossRef]

52. Gregorini, P. Diurnal grazing pattern: Its physiological basis and strategic management. Anim. Prod. Sci. 2012, 52, 416-430. [CrossRef] 